\title{
Naga Artistic Work in the Northeastern Region of Thailand
}

\author{
Mettha Sirisuk ${ }^{1}$, Arkom Sangiamvibool ${ }^{1} \&$ Vuthipong Roadkasamsri ${ }^{1}$ \\ 1 The Faculty of Fine and Applied Arts, Mahasarakham University, Khamriang Sub-District, Kantarawichai \\ District, Maha Sarakham Province, Thailand \\ Correspondence: Mettha Sirisuk, The Faculty of Fine and Applied Arts, Mahasarakham University, Khamriang \\ Sub-District, Kantarawichai District, Maha Sarakham Province, Thailand. E-mail: msirisuk159@hotmail.com
}

Received: June 22, 2014 Accepted: July 3, 2014 Online Published: September 22, 2014

doi:10.5539/ach.v7n1p58 URL: http://dx.doi.org/10.5539/ach.v7n1p58

\begin{abstract}
This research, Naga artistic work in the Northeastern region of Thailand aims to study the concepts and artistic form of Naga in the Northeastern region of Thailand. A qualitative research method was used. The researchers studied a total of 58 artistic works, divided into four groups: 5 paintings, 27 sculptures, 21 architectural structures and 5 handicraft products. The samples included Naga artworks that were created and located among 14 provinces in Northeastern Thailand. Data was collected by document retrieval from textbooks, literature and research documentaries, artistic exploration with photography and sketching and interviews with informants. Results show that there are various styles of Naga artistic work in Northeastern Thailand. All three parts, head, body and tail are direct results of Naga artwork formation having different features and meanings. Even if designs differ and some combine other animals, people still recognized the identity of a snake-like Naga. Northeastern Thailand is a huge region with a varied ethnic make-up and a long social history representing religion, beliefs, political change and development. These are the factors affecting lifestyle, art and culture like a great number of Naga artistic works appearing in this region. Those artworks were built by various races of artist and also were artistically influenced by other nations. Naga artistic work is a representation of an imaginary animal tied with human beliefs. The Naga image is used as a symbol of Northeastern lifestyle and represents many meanings.
\end{abstract}

Keywords: Naga, artistic work, Northeastern Thailand, culture, beliefs

\section{Introduction}

Art is a diverse range of human activities and products which have been created and used as media of thinking and personal feelings towards the surrounding social context. It is an emotional transmission that depends on individual humans from each area, race, religion, language and environment. These factors affect representation style and contribute to various art forms, which are not only aesthetically valuable but also contain many aspects of human ethnic history.

Nature creates everything and is the greatest base for knowledge. Humankind has explored and used nature to survive and has transmitted its experiences from generation to generation. These experiences affect human ability to do more complicated lifestyle activities, creating social connections to imagination, religion or belief and other controllable and uncontrollable things. These become driving forces directly against human life and also the inspiration with which humans try to communicate. This leads to abstract thinking and concrete representation as art: literature, architecture, music and dance. Many artistic works from primitive eras have been inspired by human surroundings. The snake is one creature that humans have selected and used as a symbol of art. James George Fraser studied about the culture of human beliefs and Carl Gustav Jung studied the principles and symbols which humans used in ancient society. Both found that people in many regions use the image of the snake as a national symbol or sign (Eaw-Sriwong, 2005).

Snakes are commonly found everywhere in nature and their long and legless figure gives them a different identity from other animals. Many species of snakes possess deadly venom, which affords them an air of power. Humans in primitive eras, who lacked of knowledge and cognition, would be frightened of snakes and believed that people could satisfy snakes with sacrifices. By revering the snake in a god-like manner, people believed they would be safe. This is why many snake-worshiping cults occurred worldwide, from Egypt to Greece, Japan to 
Thailand. The snake worshipping ceremonies of these cults are recounted in literature, legends and artistic works.

There is an interrelationship between Naga and snake. In the Royal Institute Dictionary (RID) BE 2542 (Ministry of Education, 1999), Naga means hooded snake or snake with a comb. In Sanskrit, Naga is a cobra, a specific type of snake (Wongted, 2000). The Northeastern Thai Dictionary explains that Naga is a huge snake with a comb, a mythical animal and Phraya Naga is the king of snakes (Ministry of National Culture Office, 1983). Thai historical and archeological research has uncovered many artistic works showing respect for the Naga or snake at least three thousand years ago, during the prehistoric period. Many of these works have been found in the Northeastern region of Thailand. When Buddhist and Brahman expansion caused the establishment of religious places, images and sculptures the legends of the Naga became known as Buddhist symbolism, affecting Naga imagery in many Northeastern Thai Buddhist art works. Thus, belief in the Naga of Northeastern Thailand began and has been inherited since prehistory, influencing Naga in Buddhism, Brahmanism, the Dvaravati Kingdom, the Lopburi era and even present Mekong river bay communities (Jindawattanaphum, 1999). However, the Naga is one of the only animals not really existing in empirical biological framework. The Naga is a byproduct of human imagination under the context of cultural art in each community. It is created so that people can feel and recognize its physical features through various forms of art (Saipun, 1996). Despite present world social development by the new technology and related structures, artistic work has been maintained to act as the agent from the past that tells the story of humanity over time. Artistic work is evidence of national aesthetic wealth, helping people to explore history (Phoonumphol, 2009).

The research team was thus interested in studying the concepts and artistic forms of Naga artwork in Northeastern Thailand. This study assumes to rely on information from history, folk tales, mythology and archeological places and objects, helping the researchers to see the relative structures between groups of people in the community, performances and Naga symbolism in non-artistic work, which later leads us to understand how people bind their Naga beliefs with concepts, styles and symbolic representation.

\section{Research Methodology}

This research, Naga artistic work in the Northeastern region of Thailand aims to study the concepts and artistic form of Naga in the Northeastern region of Thailand. A qualitative research method was used. The researchers studied a total of 58 artistic works, divided into four groups: 5 paintings, 27 sculptures, 21 architectural structures and 5 handicraft products. The samples included Naga artworks that were created and located among 14 provinces in Northeastern Thailand: Kalasin, Khon Kaen, Nakhon Phanom, Nakhon Ratchasima, Buriram, Mahasarakham, Mukdahan, Yasothon, Roi Et, Loei, Nong Khai, Amnat Charoen, Udon Thani and Ubon Ratchathani.

Data was collected by document retrieval from textbooks, literature and research documentaries, artistic exploration with photography and sketching and interviews with informants (Figure 1). The informants were divided into three groups: 1) Artistic informants; 2) Anthropological and historical informants; and 3) Informants in the community who most closely deal with art work. Data was analyzed through interpretation and content analysis. The research results are presented here as a descriptive analysis.

\section{Results}

\subsection{Naga Artistic Form}

\subsubsection{Naga Physical Form}

The researchers found that the shape and figure of Naga on various types of artwork in the study area were quite varied. The visual perception is both two and three dimensional, created with material depending on function; this represents the diversity of artist wisdom, capability and experience. Although Naga physical appearance detail is different, there are three essential components appearing on every Naga artistic work found in this study: 1) head, 2) body and 3) tail (Table 1). Naga figures in some artworks or objects were incomplete due to the principle use and position, for example Naga figures on the headstock of Phin (a type of local lute) from the research institute of North-eastern art and culture, Mahasarakham province or the Naga head on the spinning wheel at Kham Poon village, Ubon Ratchathani Province. 


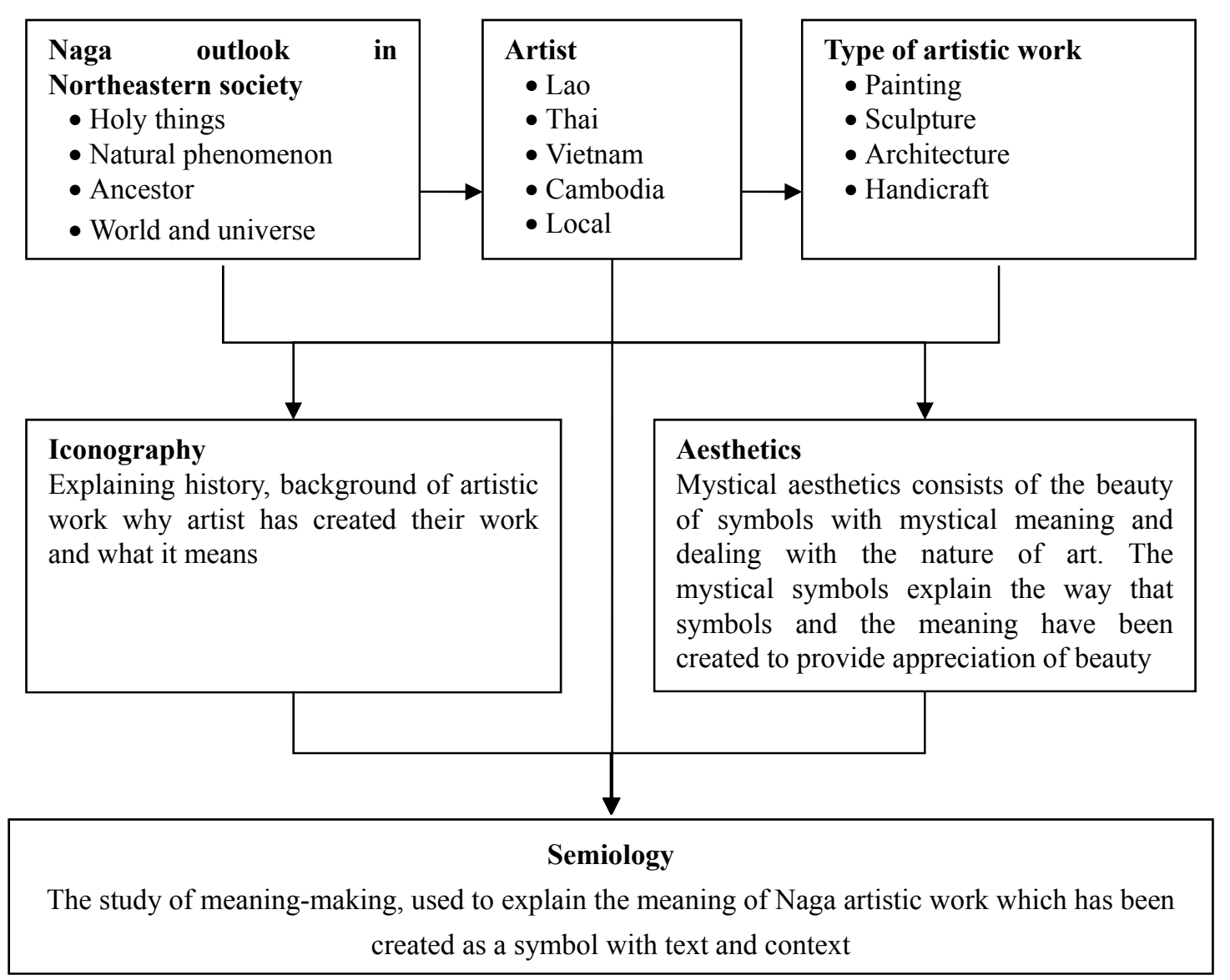

Figure 1. Research framework

Table 1. Frequency of physical structures in Naga artistic work

\begin{tabular}{lllcc}
\hline Sample (Naga artwork) & & & Frequency & Percentage \\
\hline \multirow{3}{*}{ Position } & High & & 36 & 62 \\
& Middle & & 19 & 33 \\
\multirow{3}{*}{ Dimensions } & Low & & 9 & 16 \\
& $2 \mathrm{D}$ & & 10 & 17 \\
& $3 \mathrm{D}$ & & 48 & 83 \\
& & More than one head & 7 & 12 \\
& & Crest & 56 & 97 \\
& \multirow{4}{*}{ Head } & Beard & 49 & 84 \\
& & Horn & 2 & 3 \\
& & Ears & 5 & 9 \\
& & Wings & 15 & 26 \\
& \multirow{4}{*}{ Bodysical appearance } & Legs & 3 & 5 \\
& & Composed with other animal & 7 & 12 \\
& & Tes & 52 & 90 \\
& Tail & No & 6 & 10 \\
\hline
\end{tabular}

The researchers found that the Naga heads consisted of important features: crest, beard horn and ears. Naga artwork head formation in Northeastern Thailand was varied: Snake-like, dragon-like, lion-like or similar to other animals, with both single and multiple heads (3-9 heads are related to religious belief). One more interesting aspect of these Naga heads is that some Naga faces were influenced from other countries, for example some Naga faces look like dragons and lions that were created by Vietnamese and Khmer artists or had been influenced from China. 


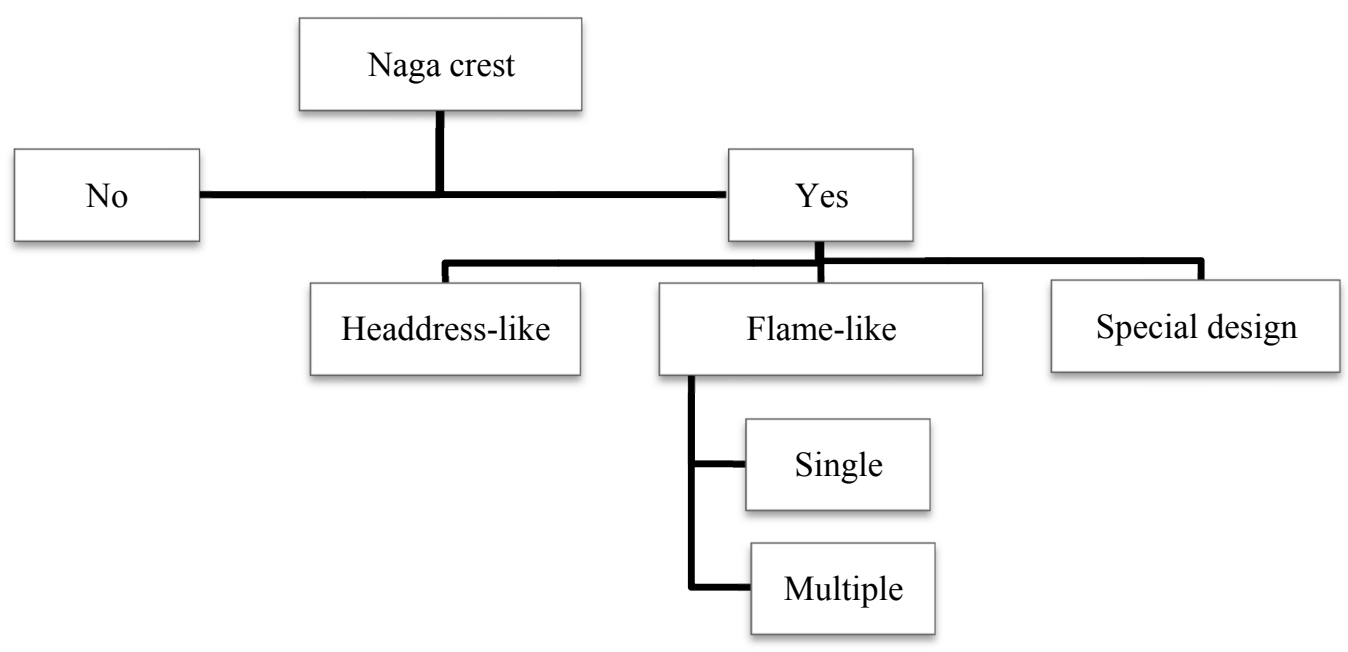

Figure 2. Naga crests in Naga artwork
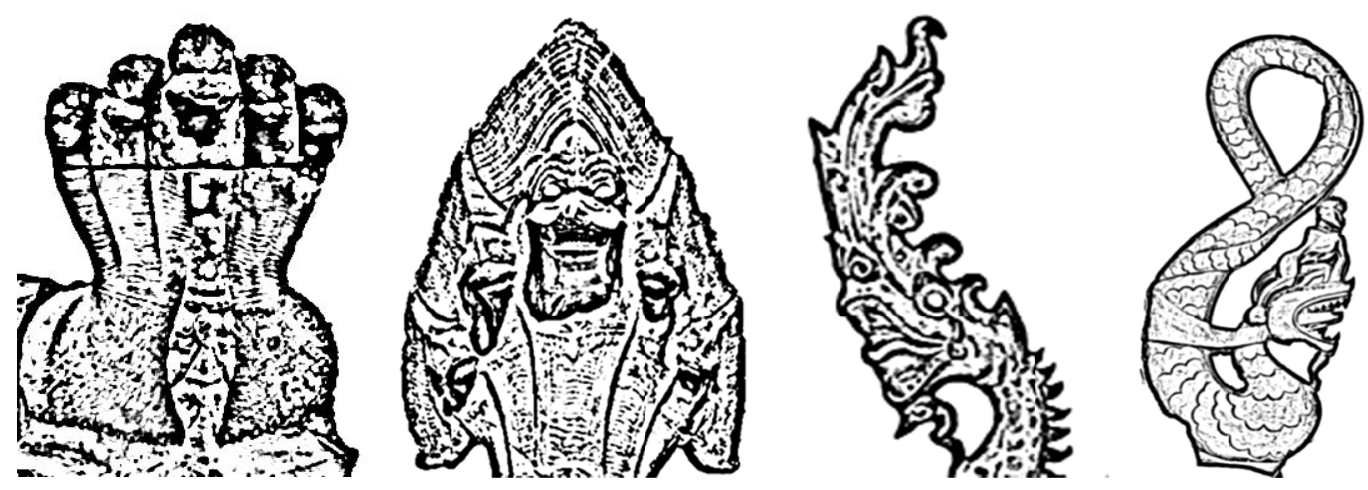

Figure 3. Type of Naga crest

In figure 2 (Figure 2) and figure 3 (Figure 3), the researchers divided the Naga crest appearance into 4 types. The first type is a headdress-like crest, artistically influenced from Khmer and mostly found in stone sculptures according to the technical limitations of the stone-sculpting processes, for example Naga statues in Phimai historical park, Nakhon Ratchasima province. The second type is a flame-like crest, the most common crest type found on artistic works such as Naga heads on the headstock of Phin from the research institute of North-eastern art and culture, Mahasarakham province and also on fabric patterns, for example the Ikat silk from Loei province. Both have single and multiple flames. The third type is a special design reflecting the imagination of the artist. The last type is without a crest. A few Naga heads with no beard appeared in artwork artistically influenced from Khmer and found in stone sculptures. Almost all beards appearing on Naga heads were created by Vietnamese artists inspired by Chinese art. In addition, many images of the Buddha show beardless Naga over his head. Some Naga heads show small horns and ears, like those of a deer.

The researchers found the shape of the body of Naga artwork in Northeastern Thailand to have different details. Not only did they have long figures like a snake but also additional organs, such as wings, legs and feet. Some Naga artwork shows body figures combined with other animals: crocodiles, frogs and elephants, for example the holy water sprout with elephants spewing up from the Naga figure design and a Naga head spewed out by a frog figure on a wooden spinning wheel at Kham Poon village, Ubon Ratchathani province. According to this investigation, almost all Naga artwork was designed with an ' $S$ ' body shape (Figure 4) at the connecting part between the head and body. In the principles of nature a snake will make a posture in the shape of an ' $S$ ' before attacking prey or protecting itself. The body structure occurring in artwork may not only show moving lines but also intend to create more formidable powers than other common snakes in nature. The body structure was created corresponding to the artwork features it comprised. 

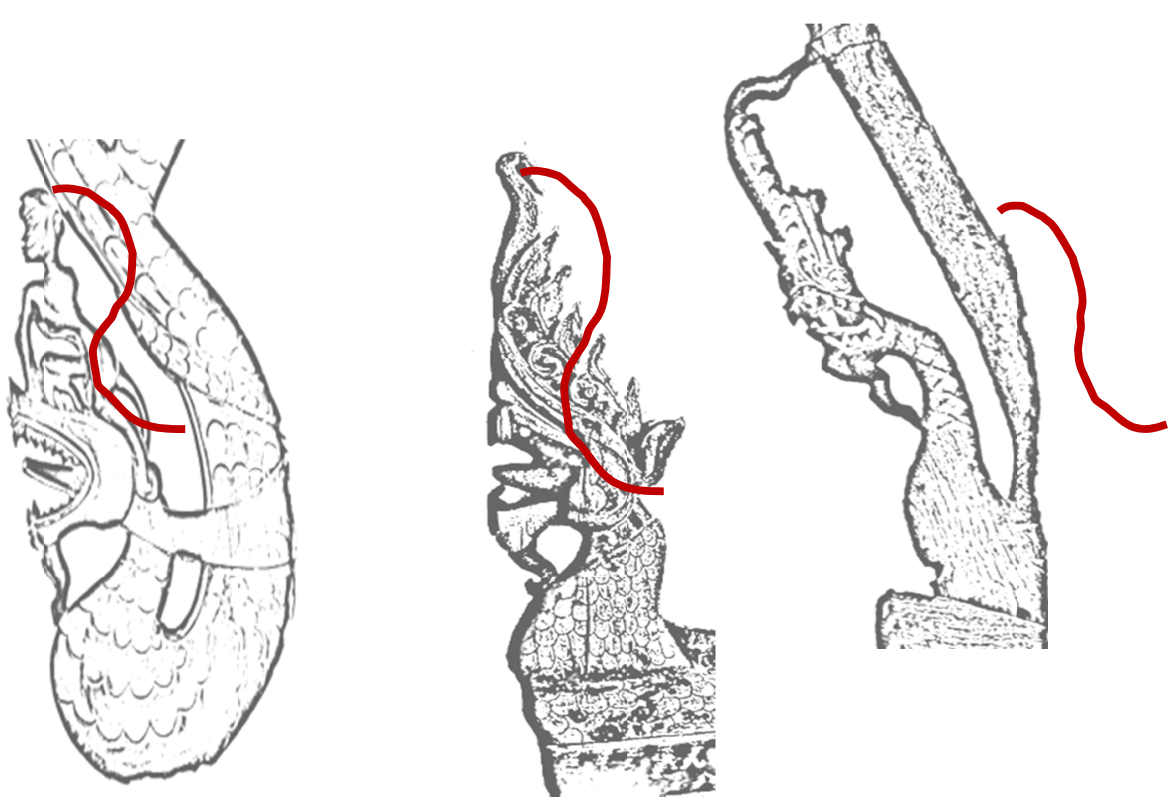

Figure 4. S-shape of Naga line structure

\subsubsection{Naga Significance according to Artistic Family}

In the following table (Table 2), the researchers have grouped Naga artistic work significance according to artistic family: Khmer art, Vietnam art, Lao art.

Table 2. Naga artistic work significance according to artistic family

\begin{tabular}{|c|c|c|c|}
\hline $\begin{array}{l}\text { Artistic } \\
\text { family }\end{array}$ & Khmer (Figure 5) & Vietnam (Figure 6) & Tai-Lao (Figure 7) \\
\hline $\begin{array}{l}\text { Influencing } \\
\text { nation }\end{array}$ & India, China & China, West, France & $\begin{array}{l}\text { Cambodia, Lan Xang, Siam, } \\
\text { Khmer, Myanmar }\end{array}$ \\
\hline Material & Stone & Moled figure, Painting & $\begin{array}{l}\text { Fabric, Wood, Cement, Metal, } \\
\text { Other local material }\end{array}$ \\
\hline $\begin{array}{l}\text { Naga } \\
\text { appearance } \\
\text { types }\end{array}$ & $\begin{array}{l}\text { Bald head Naga is } \\
\text { similar to general } \\
\text { snake in nature but } \\
\text { has a flattened } \\
\text { mouth like a duck } \\
\text { bill, for example the } \\
\text { Naga sculpture on } \\
\text { the cage of } \\
\text { Muang-Tum stone } \\
\text { castle, Buri Ram } \\
\text { province } \\
\text { Naga with headdress } \\
\text { crest like a fascia } \\
\text { sheath attached on } \\
\text { the top of the Naga } \\
\text { looking like a } \\
\text { crown, for example } \\
\text { the Naga sculpture } \\
\text { at Phanom Rung }\end{array}$ & $\begin{array}{l}\text { Dragon-like Naga with } \\
\text { whiskers, mane, legs } \\
\text { and claws, such as } \\
\text { Naga on Buddhist } \\
\text { monastery walls at } \\
\text { Udom Prasharat } \\
\text { temple, Kalasin } \\
\text { Province, and Naga } \\
\text { wall painting at } \\
\text { Srinuan Sawangarom } \\
\text { temple, Ubon } \\
\text { Ratchthani Province } \\
\text { Dog-like Naga has } \\
\text { extended Naga face } \\
\text { with big nose, wide } \\
\text { grinning mouth and } \\
\text { multiple flame crest. } \\
\text { This Naga type is } \\
\text { mostly found on the }\end{array}$ & $\begin{array}{l}\text { Snake-like Naga with } \\
\text { a long, slender body } \\
\text { shape with scales, no } \\
\text { crest and beard and } \\
\text { face features similar } \\
\text { to a real snake. This } \\
\text { artwork design has } \\
\text { occurred since } \\
\text { prehistory. In } \\
\text { addition, this } \\
\text { represented } \\
\text { snake-worshiping } \\
\text { until changing to a } \\
\text { Naga due to the } \\
\text { religious role in } \\
\text { society. } \\
\text { Naga with crest and } \\
\text { beard, the most } \\
\text { common Naga type }\end{array}$ \\
\hline
\end{tabular}




\begin{tabular}{|c|c|c|c|}
\hline $\begin{array}{l}\text { Artistic } \\
\text { family }\end{array}$ & Khmer (Figure 5) & Vietnam (Figure 6) & Tai-Lao (Figure 7) \\
\hline $\begin{array}{l}\text { Artistic } \\
\text { type }\end{array}$ & $\begin{array}{l}\text { stone castle, Buri } \\
\text { Ram province and } \\
\text { Phimai stone castle, } \\
\text { Nakhon Ratchasima } \\
\text { Province } \\
\text { Lion-face Naga also } \\
\text { was found at } \\
\text { Phanom Rung stone } \\
\text { castle and was } \\
\text { created in Nakhon } \\
\text { Wat era, Chinese } \\
\text { artistry influence. } \\
\text { This Naga } \\
\text { appearance was } \\
\text { similar to Chinese } \\
\text { lion face: round and } \\
\text { big eyes, grinning } \\
\text { mouth. }\end{array}$ & $\begin{array}{l}\text { handrail of temple } \\
\text { stairs, for example the } \\
\text { Naga at North Khon } \\
\text { Kaen temple, Khon } \\
\text { Kaen Province and the } \\
\text { Naga sculpture on } \\
\text { handrails of stairs at } \\
\text { Saphan Khum temple, } \\
\text { Sakon Nakhon. } \\
\text { Mixed species Naga is } \\
\text { combined with organs } \\
\text { of other good fortune } \\
\text { animals such as } \\
\text { Cygnus, Garuda or } \\
\text { angels. This causes the } \\
\text { figure of the Naga to } \\
\text { become dissimilar to } \\
\text { other general Naga } \\
\text { artwork. Mostly long } \\
\text { and snake-like but } \\
\text { some have legs. This } \\
\text { creation clearly reflects } \\
\text { the cross-species } \\
\text { combination. This type } \\
\text { of Naga artwork was } \\
\text { only found in } \\
\text { Photharam temple, } \\
\text { Mahasarakham } \\
\text { province. } \\
\text { Architecture } \\
\text { Painting }\end{array}$ & $\begin{array}{l}\text { found in } \\
\text { Northeastern } \\
\text { Thailand, with a } \\
\text { long, legless body } \\
\text { like a big snake and } \\
\text { flame-like crest: both } \\
\text { single and multiple } \\
\text { flame. This Naga } \\
\text { artwork design was } \\
\text { usually used in every } \\
\text { type of artistic work. } \\
\text { Decorated Naga, an } \\
\text { outstandingly } \\
\text { designed, snake-like } \\
\text { Naga with crest, } \\
\text { beard, wings and } \\
\text { horns but no legs. } \\
\text { This artwork design } \\
\text { is also found in } \\
\text { literature and is } \\
\text { influenced by China } \\
\text { but is not like a } \\
\text { dragon or Chinese } \\
\text { Lion } \\
\text { Spewed-out Naga, } \\
\text { poking its head out of } \\
\text { the mouths of other } \\
\text { animals, such as } \\
\text { crocodiles, dragons, } \\
\text { frogs or elephants. } \\
\text { Handicraft } \\
\text { - Literature } \\
\text { Architecture } \\
\text { - Sculpture } \\
\text { Painting }\end{array}$ \\
\hline
\end{tabular}

1)
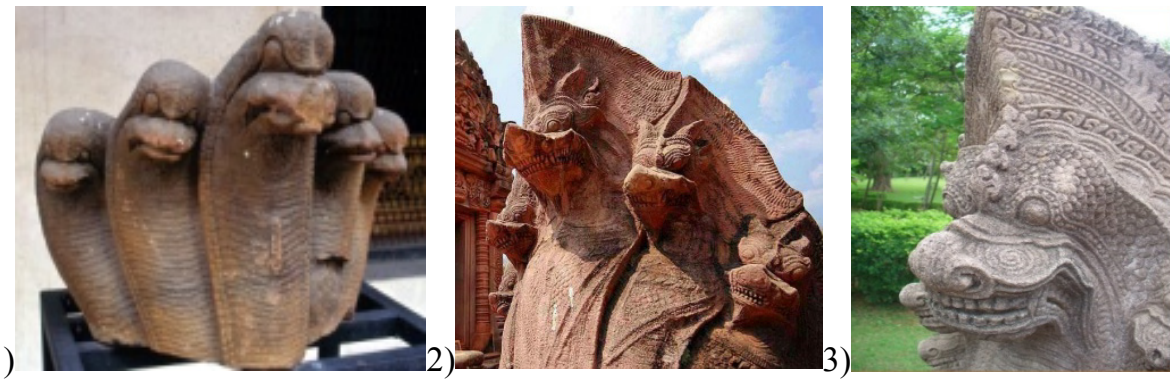

Figure 5. (1) Bald head Naga, (2) Naga with headdress crest, (3) Lion-face Naga 

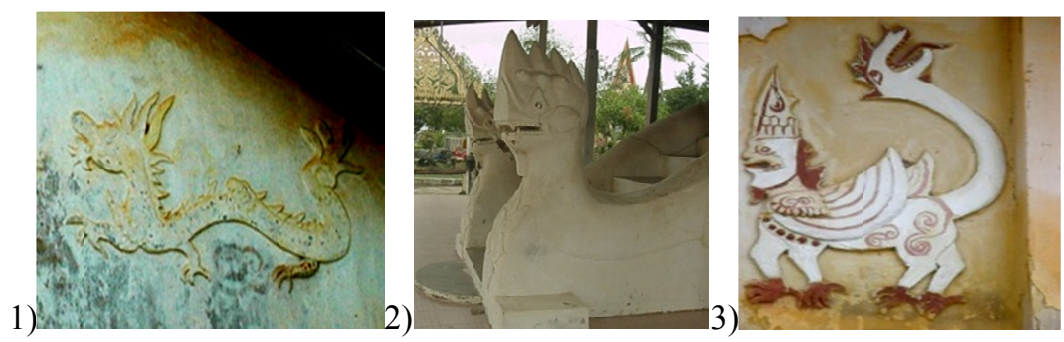

Figure 6. 1) Bald head Naga, 2) Dog-liked Naga, 3) Mixed species Naga
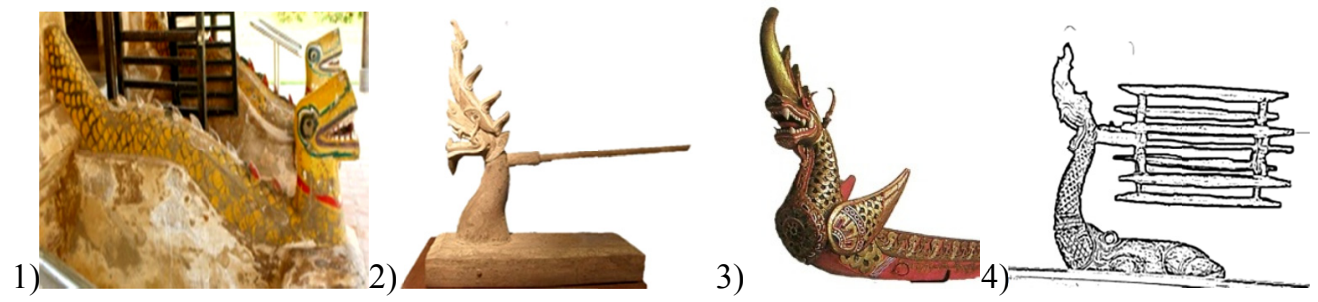

Figure 7. 1) Snake-like Naga, 2) Naga with crest and beard, 3) Decorated Naga, 4) Spewed-out Naga

\subsection{Concept Affecting Naga Artistic Work Creation}

According to this study, each artwork is overlapped by several meanings and the image of the Naga also becomes a symbol of many things. To convey the idea of Naga through artistic work responding to the need to transmit beliefs and signs, the artist has to consider the shape, features, structure and position of the Naga in their artwork. This is not only aimed to influence the artwork appearance but also to connect to human belief. Thus, the Naga will have more meaning than an imaginary snake with a crest. In addition, images of Naga are currently used as different signs, such as trademarks or logos of places and organizations. Concepts and beliefs about snakes and Naga have been settled in community ideology for a long time. These local beliefs can be divided into four viewpoints (Table 3).

Table 3. Northeastern perspectives of Naga

\begin{tabular}{|c|c|c|c|}
\hline Naga perspective & Detail & Naga symbol & Artistic work \\
\hline The Naga is holy & $\begin{array}{l}\text { The Naga is a powerful } \\
\text { supernatural being, which } \\
\text { has good fortune and } \\
\text { greater status }\end{array}$ & $\begin{array}{lr}\text { Holy } & \text { thing, } \\
\text { guardian and } \\
\text { protector }\end{array}$ & $\begin{array}{l}\text { Decorated Naga or Naga with } \\
\text { headdress-crest, horns, wings, feet etc. } \\
\text { Features performed as lined, structural } \\
\text { sculptures found in fine architecture }\end{array}$ \\
\hline $\begin{array}{l}\text { The Naga has } \\
\text { human origin }\end{array}$ & $\begin{array}{l}\text { The Naga is the great } \\
\text { ancestor giving birth to } \\
\text { several races and tribes }\end{array}$ & Mother & $\begin{array}{l}\text { Found in fabric patterns, tattoos, } \\
\text { weaving tools and folk literature }\end{array}$ \\
\hline $\begin{array}{l}\text { The Naga is related } \\
\text { to natural } \\
\text { phenomenon }\end{array}$ & $\begin{array}{l}\text { The Naga is god of water } \\
\text { and rain, the creator of } \\
\text { world abundance }\end{array}$ & $\begin{array}{l}\text { Water, earth, } \\
\text { rain, abundance }\end{array}$ & $\begin{array}{l}\text { Naga figure on water sprout, fabric } \\
\text { patterns, fine architecture and } \\
\text { handicrafts }\end{array}$ \\
\hline $\begin{array}{l}\text { The Naga links the } \\
\text { world and the } \\
\text { heaven together }\end{array}$ & $\begin{array}{l}\text { The Naga is a part of both } \\
\text { human world and another } \\
\text { cosmos, linking humanity } \\
\text { to heaven }\end{array}$ & $\begin{array}{l}\text { Connective } \\
\text { bridge between } \\
\text { two worlds }\end{array}$ & $\begin{array}{l}\text { Found in fine architecture, bridges, } \\
\text { thrones, funeral chariots, Naga brocades, } \\
\text { musical instruments etc. }\end{array}$ \\
\hline
\end{tabular}

\section{Conclusion}

There are various styles of Naga artistic work in Northeastern Thailand. All three parts, head, body and tail are direct results of Naga artwork formation having different features and meanings. Even if designs differ and some combine other animals, people still recognized the identity of a snake-like Naga. Northeastern Thailand is a huge 
region with a varied ethnic make-up and a long social history representing religion, beliefs, political change and development. These are the factors affecting lifestyle, art and culture like a great number of Naga artistic works appearing in this region. Those artworks were built by various races of artist and also were artistically influenced by other nations. Naga artistic work is a representation of an imaginary animal tied with human beliefs. The Naga image is used as a symbol of Northeastern lifestyle and represents many meanings.

\section{Discussion}

Even though the Naga was imagined by humans, its features still originate from those of a snake. The prince Narisara Nuvadtivong, Prince of Siam, explained that Naga came from snakes with different added organs, depending on human imagination (Satian Koket Foundation, 2009). Sombat Plainoi explained that Naga was a Pali word meaning snake, while Hinduism referred to Naga as a cobra. In Buddhism, Naga means the great snake and Sanskrit also defines this word as Norathep, snake with a human face. People from the western world would call an animal with a long body a Nake, relating to the word snake, which also comes from the Indian word Naga (Plainoi, 2011A, 2011B). These explanations represent the relationship between snake and Naga in meaning and linguistic background.

Most Naga featured in the Northeastern region are similar to snake figures. Chamnong Kitisakon (1990) studied Naga on vernacular sim (church) architecture in Northern Isan and found that, although Naga artistic forms in each study place were different according to artist skill, all artwork conceptual designs originated from the figures of snakes. This caused Naga to become a new symbolic figure under the snake's significance. The researchers recognized that artistic family model, raw material, use and belief were transmitted into the artwork and affected the differentiation between Naga features and fine detail appearance on artistic works. Somchai Na Phanom and Nangnoi Punchapan (1994) said that there was no actual pattern of folk artistry creation in Northeastern Thailand but they used the components combined with the surrounding environment and human beliefs. Art in ancient Thailand was created with nearby natural resources. When Buddhism and Brahmanism grew, the religious places and statues began to be created.

In the concept that Naga is a powerful supernatural thing with good fortune and greater status, Janjira Benchapong commented about animal features decorated on several tools that people in ancient times relied in their lifestyle. The people observed animal behavior and special characteristics that reptiles and amphibians had enabling them to live both on ground and under water. Therefore, people thought that those animals would have mysterious power. They became sacred and combined with the imagination to form mixed species, such as Naga or dragons. These animal features are added to various artworks and tools, for example boat coffins and musical instruments, according to the belief that these feature would help people connect to supernatural power (Benchapong, 2012).

Sonpan Wannamat studied fabric weaving patterns and found that images of Naga were shown on fabric patterns as a symbol of the mother, human tribe reproduction and abundance. This was related to religious beliefs of women who wove the fabric (Wannamat, 1991). In addition, the researchers found that Naga not only represents female symbol but also takes male status, as can be seen from the imagery of Naga tattoos on Northeastern men.

In the concept that Naga is god of water and rain, the creator of world abundance, Buddhist and Hindu principles state that the Naga was the creator who gave humans abundance (Lamai, 1995). This also corresponds to Sumet Chumsai Na Ayutthaya, who explained the meaning of Naga as a symbol of water elements (Chumsai Na Ayutthaya, 1986). Suriya Samutkub analyzed the imagery of the Naga and found that Naga was the symbol of crop abundance, an important factor of life for Northeastern people who rely on water and natural resources for their agriculture (Samutkub, 1990).

\section{Suggestions}

\subsection{Suggestions for Further Research}

Further research should concern the concept and artistic forms affecting artistic work of Naga creations compared with other regions or in other countries such as Lao, Cambodia and Vietnam. Further research should also consider the concept and artistic form affecting artistic work of Naga creation in Northwestern Thailand, where many literature and artwork related to the Naga has been created.

\section{References}

Benchapong J. (2012). Snakes, Naga \& crocodiles on Southeast Asian musical instruments [In Thai]. Siam Ratha Newspaper, 24 Feb - 1 Mar, 2012.

Chumsai Na Ayutthaya, S. (1986). Water: origin of Thai culture [in Thai]. Bangkok: Thaiwattanaphanit. 
Eaw-Sriwong, N. (2005). Naga - Naked people: A primitive study of local Southeast Asia [in Thai]. Bangkok: Amata foundation.

Jindawattanaphum, S. (1999). Naga belief of Isan communities in the Mekong river bay [in Thai]. Bangkok: Srinakharinwirot University.

Kitisakon C. (1990). Naga sculpture decorated on the vernacular sim in Northern Isan region [In Thai]. Mahasarakham: Srinakharinwirot University.

Lamai. (1995). Naga which creates abundance in life [In Thai]. Bangkok: Kinaree Journal.

Ministry of Education. (1999). Royal Institute Dictionary (RID) BE 2542 [in Thai]. Bangkok: Ministry of Education.

Ministry of National Culture Office. (1983). The Northeastern Thai dictionary [in Thai]. Bangkok: Ministry of National Culture Office.

Na Phanom, S., \& Punchapan, N. (1994). Isan wooden carvings [In Thai]. Bangkok: Roeng Rom printing.

Phoonumphol, W. (2009). Siam Culture combining with artistic work [in Thai]. Bangkok: Rungsilp Printing.

Plainoi, S. (2011A). Himavanta animal [In Thai]. Bangkok: Pimkham printing.

Plainoi, S. (2011B). Garuda grapping Naga [In Thai]. Bangkok: Pimkham printing.

Saipun, P. (1996). Nagakati: Contemporary cultural lifestyle [in Thai]. Bangkok: Thammasart University.

Samutkub, S. (1990). Significant symbols in the Thai rocket festival: Analysis and interpretation through anthropological method [In Thai]. Khon Kaen: Khon Kaen University.

Satian Koket Foundation. (2009). 'Who is Naga?' [in Thai]. SilpWattanatham Thai Journal, 14.

Wannamat, S. (1991). Isan fabric patterns [In Thai]. Bangkok: Odeon store.

Wongted, S. (2000). Naga naked local people like snake [in Thai]. Bangkok: Amata foundation.

\section{Copyrights}

Copyright for this article is retained by the author(s), with first publication rights granted to the journal.

This is an open-access article distributed under the terms and conditions of the Creative Commons Attribution license (http://creativecommons.org/licenses/by/3.0/). 